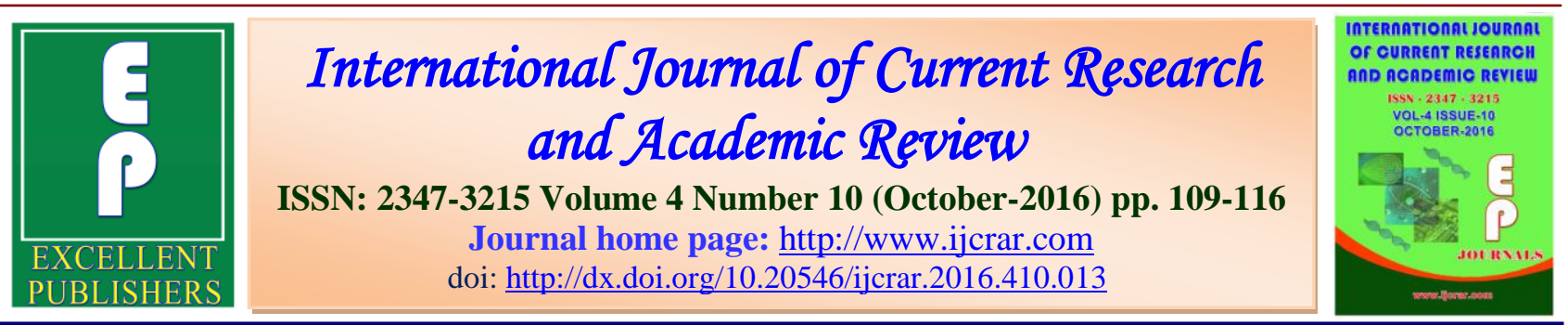

\title{
New Status of Viral Disease Incidences on Chili Pepper in Bali, Indonesia: Emerging of Yellow Vein Banding Disease
}

\author{
I.D.N. Nyana ${ }^{1 *}$, T. Rahayuningsih ${ }^{2}$, I.G.R.M. Temaja ${ }^{1}$, G.N.A.S. Wirya ${ }^{1}$ and G. Suastika ${ }^{2}$ \\ ${ }^{1}$ Udayana University, Denpasar, Bali, Indonesia \\ ${ }^{2}$ Bogor Agricultural University, Bogor West Java, Indonesia
}

*Corresponding author

\begin{tabular}{|l|l|}
\hline \multirow{2}{*}{$\begin{array}{l}\text { KEYSWOase, } \\
\text { identification, } \\
\text { nucleotide sequence, } \\
\text { Cucumovirus, } \\
\text { Potyvirus, } \\
\text { Tobamovirus. }\end{array}$} & $\begin{array}{l}\text { A B S T R A C T } \\
\text { Bali Island were conducted during growing season of } 2012-2013 \text { to } \\
\text { updating the status of viral diseases. Observations were done based on the } \\
\text { expression of symptom types on the plants in the fields, and some leaf } \\
\text { samples were collected from different plant with different symptoms to } \\
\text { elucidate viral pathogen associated with the symptoms. Virus detections and } \\
\text { identifications were done by using enzyme-linked immunosorbent assay } \\
\text { (ELISA) or by reverse transcription and/or polymerase chain reaction (RT- } \\
\text { PCR). Two viral diseases namely yellowing and mosaic, as reported } \\
\text { previously, were found to be spread throughout the region. Based on the } \\
\text { results of ELISA using sera anti-respective viruses, mosaic disease was } \\
\text { induced by one of three different viruses: Tobacco mosaic, Cucumber mosaic } \\
\text { and Chili veinal mottle viruses. Whereas, yellowing disease associated with } \\
\text { infection of Pepper yellow leaf curl virus as confirmed by PCR. A new } \\
\text { emerging disease, namely yellow vein banding, has typical symptoms and } \\
\text { simply could be differentiate from mosaic and yellowing diseases. This } \\
\text { disease still spread to a certain restricted area in Bali. RT-PCR using a pair } \\
\text { primers specific to Pepper vein yellows virus (PeVYV) successfully } \\
\text { amplified a DNA band of about } 650 \text { bp from the diseased sample plants. The } \\
\text { nucleotide sequences read directly from the RT-PCR product has a high } \\
\text { homologies (more than 90\%) with those of PeVYV from other countries. This } \\
\text { result confirmed the association of PeVYV with a new emerging chlorosis } \\
\text { disease on chili pepper in Bali. }\end{array}$
\end{tabular}

\section{Introduction}

Chili pepper being cultivated in Indonesia was mostly belongs to species Capsicum annum $\mathrm{L}$. and only a few belongs to $C$. frutescent L. Having a wide adaptability, chili pepper could be found cultivated from lowland to upland of the area. The fruit can 
be classified as vegetables and spices, depending on how it was used. As a seasoning, spicy chili pepper was very popular in Indonesia as well as in Southeast Asia as a food flavor enhancer (Vos and Duriat, 1995).

In Bali and other area of Indonesia, most chili pepper crops are generally grown throughout the year. In most area, the crop was grown in small plots and mixed with the particular crop dependent on the season (Nyana et al., 2012). Until now, low quality of seed materials, high production costs, fluctuating market prices, and poor crop health management are still major production constraints in the area.

Improvement of cultural techniques by intensive cultivation of chili pepper conducted to increase production was still give no positive result because of high incidence of viral disease. Viruses have been found as the most devastating disease causing agents of chili pepper, causing serious losses (Berke, 2002). Chili pepper is naturally susceptible to a wide range of viruses in all Southeast Asian countries including Indonesia (Green, 1991).

There were two different viral diseases faced to chili pepper in the area: one was yellowing disease that has been known to be associated with infection of Pepper yellow leaf curl virus (PepYLCV), a begomovirus (De Barrow et al., 2008). Other disease is mosaic disease that has been observed in the last five years and it becomes an important disease following a long dry season in 2013 throughout Bali.

The disease symptoms are characterized by light and dark green mottling on the leaves. Based on the type of symptoms, more than one viral pathogen was suspected to be associated with the disease of chili pepper in Bali Island.
Two years ago, a new disease on chili pepper was observed in restricted area of Bali. Leaves of diseased plant exhibited yellowing appearance with interveinal chlorosis but the vein still with normal green color (yellow vein banding disease) (Suastika et al., 2012). This disease symptom is different from that of induced by viruses reported present in Indonesia before. The disease was similar with that of induced by Polerovirus reported from other countries.

The present study was conducted to monitor viral diseases throughout Bali Island, to assess the crop condition as well as to collect information regarding prevalence, distribution and occurrence of viruses so that management strategies can be devised to minimize crop losses.

\section{Materials and Methods}

\section{Surveys for viral disease incidence and sample collection}

Surveys of chili pepper crops for viruses recorded in Bali, as listed in Table 1, were undertaken during 2013-2014 over the wet periods in representative crops and cropping areas around districts of Badung, Bangli, Buleleng, Denpasar, Gianyar, Jembrana, Karangasem, Klungkung and Tabanan. Crops were surveyed along crop rows or in a "W" pattern and visual estimates of virus incidence recorded. Incidence was estimated particularly from observations of plant yellowing, yellow vein banding and mosaic symptoms, separately.

Chili pepper plants were examined at each location. Individual representative leaf and plant specimens were collected from chili pepper plants showing symptoms characterized by yellowing, yellow vein banding and mosaic similar to those caused 
by virus. Samples, consisting of about $1 \mathrm{~g}$ fresh weight of young leaves or shoot tips showing disease symptoms were desiccated over anhydrous calcium chloride (about $7 \mathrm{~g}$ ) in sealed, $25 \mathrm{ml}$ plastic vials. Samples were stored at $4{ }^{\circ} \mathrm{C}$ until fully desiccated. Laboratory examination included enzymelinked immunosorbent assays (ELISA) and reverse transcription-polymerase chain reaction (RT-PCR).

\section{Enzyme-Linked Immunosorbent Assays (ELISA)}

About 5\% chili pepper showing mosaic symptom samples from all surveys were tested for virus infection using double antibody sandwich (DAS)-ELISA . DASELISA was performed for the detection of CMV and ChiVMV in the collected plant samples. CMV-specific antibodies along with alkaline phosphatase-linked antibodies procured from DSMZ (Germany) were subjected for ELISA as manufacturer's instruction and as method where ELISA tests were performed using potyvirus groupspecific polyclonal antibodies to detect ChiVMV. Direct-ELISA was performed according to the manufacturer's protocols (Agdia Inc., USA) for TMV detection. All ELISA test samples were considered positive when absorbance values exceeded three times the mean of appropriate healthy controls that were included on each microtiter test plate.

\section{Total RNAs Extraction}

Total RNAs was isolated from yellow vein banding symptom shown chili pepper leaf samples following manufacturer protocol (Thermo Scientific, Lithuania). Fresh tissue $(0.1 \mathrm{~g})$ was ground in liquid Nitrogen to powder, $500 \mu 1$ of Plant RNA Lysis Solution was added and the sap was transferred to 1.5 $\mathrm{ml}$ clean tube, and then was vortexed $10-$
$20 \mathrm{~s}$ thoroughly. The sap was incubated in water bath at $56^{\circ} \mathrm{C}$ for $3 \mathrm{~min}$, then centrifuged at $14000 \mathrm{rpm}$ for $5 \mathrm{~min}$. The supernatant was pipetted to $1.5 \mathrm{ml}$ clean tube, $96 \%$ ethanol was added and mixed by pipetting. The liquid was transferred to a purification column inserted in a collection tube and was centrifuged at $12000 \mathrm{rpm}$ for $1 \mathrm{~min}$ and then discarded flow-through. The purification column was added $700 \mu$ of Wash Buffer WB 1 then was centrifuged at $12000 \mathrm{rpm}$ for $1 \mathrm{~min}$ and then discarded flow-through. The purification column was placed into a clean $2 \mathrm{ml}$ collection tube and was added $500 \mu \mathrm{l}$ Buffer 2 then was centrifuged at $12000 \mathrm{rpm}$ for $1 \mathrm{~min}$. The solution was discarded flow-through and repeat the additional of $500 \mu$ Buffer 2 using maximum speed of centrifugation. The collection tube was discarded flow-through and the purification column was transferred to aRNase-free $1.5 \mathrm{ml}$ collection tube. The purification column was added $50 \mu \mathrm{l}$ of nuclease free water to elute the RNA. The column was centrifuged at $12000 \mathrm{rpm}$ for 1 min and then discarded the purification column. The RNA which was kept on a collection tube was used as template in RTPCR.

\section{Reverse transcriptase- polymerase chain reaction (RT-PCR)}

RT-PCR was carried for polerovirus associated with yellow vein banding disease. Amplification was conducted using one-step RT-PCR method. RT-PCR reaction contains $12.5 \mu \mathrm{l}$ Go Taq Green PCR master mix (Fermentas, US), $10 \mu \mathrm{M}$ each of primer, $2.0 \mu \mathrm{l}$ DTT $50 \mathrm{mM}, 0.1 \mu \mathrm{l}$ RNAse Inhibitor, $0.1 \mu \mathrm{MMuLV}, 0.5 \mu \mathrm{l}$ $\mathrm{MgCl}, 2.0 \mu \mathrm{l}$ RNA total, and the reaction was adjusted to $25 \mu \mathrm{l}$ with nuclease free water. Amplifications was performed in GeneAmp PCR System 9700 machine with $60 \mathrm{~min}$ at $42.0^{\circ} \mathrm{C}$ and $2 \mathrm{~min}$ at $94.0^{\circ} \mathrm{C}$ for 
RT, $5 \mathrm{~min}$ at $94.0^{\circ} \mathrm{C}$ for pre-heating, followed by 30 cycles of denaturation ( 1 $\min$ at $\left.94.0^{\circ} \mathrm{C}\right)$, annealing $(1 \mathrm{~min}$ at $50.0^{\circ} \mathrm{C}$ ), and extension $\left(3 \mathrm{~min}\right.$ at $\left.72.0^{\circ} \mathrm{C}\right)$. The last cycle was ended at $72.0^{\circ} \mathrm{C}$ for 3 min and cooled down to $4.0^{\circ} \mathrm{C}$. Electrophoresis was done using $1 \%$ Agarose gel in $0.5 \mathrm{x}$ TBE (Tris-Boric acidEDTA) buffer, run at $50 \mathrm{~V}$ for $50 \mathrm{~min}$. Following electrophoresis, agarose gel then was soaked on to $0.1 \% \mathrm{EtBr}$ for $5 \mathrm{~min}$, washed with $\mathrm{H}_{2} \mathrm{O}$, and visualized under UV transilluminator.

\section{Results and Discussion}

\section{Prevalence of viral disease on chili pepper in Bali}

Major diseases showing yellowing and mosaic symptoms were found on chili pepper growing areas in Bali. The plants with yellowing symptom exhibited leaf distortion, interveinal and marginal leaf chlorosis, upward curling of leaf margins of older leaves, while the plants with mosaic symptom showed difference appearance as shown on Figure 1.

The plants with mosaic symptoms showed light and dark green mottling on the leaves. The dark green areas tend to be somewhat thicker than the lighter portions of the leaves. The leaf mottling was obvious if the affected plant surface was partially shaded. Young leaves exhibited vein mottling, lateral leaves were narrower than older ones, older leaves curl downward and may be slightly distorted. The infected plants produced poor quality of fruits and low yields (Figure 1).

A new disease found in the area during observation is yellow vein banding. Leaves of diseased plant exhibited yellowing appearance with interveinal chlorosis but the vein still with normal green color (vein banding, Figure 1).

Prevalence of the mosaic disease on the chili pepper growing areas in Bali was higher than that of yellowing disease (Table 1). The average percentage of chili pepper plants showing mosaic symptom was $34.6 \%$, higher than that of the yellowing disease that only $29.2 \%$. These results suggested that mosaic disease may play the most important role as one of chili pepper production constraints among viral diseases in the area. The new viral disease, yellow vein banding, occur on chili pepper in Bali in a restricted area that was just in Gianyar, Klungkung and Tabanan districts. The incidence was still low of average about $5.2 \%$.

\section{Viruses Associated with Mosaic Disease on Chili Pepper in Bali}

In Indonesia, the yellowing disease has been known to be caused by infection of a begomovirus, PepYLCV (De Barrow et al., 2008) that is transmitted by Bemisia tabaci. But, the pathogen of the mosaic disease has not been confirmed until now. Based on ELISA test using antisera corresponding to the viruses, the viruses found in the mosaic diseases in chili pepper in this study were TMV, ChiVMV, and CMV (Table 2). Among them, CMV and ChiVMV were the dominant viruses with prevalence by $29.4 \%$ and $26.4 \%$, respectively, followed by TMV with prevalence by $14.7 \%$. This result indicated that CMV and ChiVMV are important and the main cause of mosaic disease on chili pepper in Bali.

\section{Yellow Vein Banding, A New Emerging Disease on Chili Pepper in Bali}

PCR using Polerovirus universal primer successfully amplified a DNA band of about 650bp if subjected to total RNAs extracted 
Int.J.Curr.Res.Aca.Rev.2016; 4(10): 109-116

from chili pepper showing yellow vein banding symptoms (Figure 2). This evidence give a clue that the virus species is a member of Polerovirus.

Nucleotide sequences were obtained directly from PCR product. Analysis of their identity by comparing to sequences on the GenBank showed their high homology with Pepper vein yellow virus from around the world (more than 97\%, Table 3). Its homology to Potato leafroll virus, another virus causing disease on chili, is only about $62 \%$. This result indicated that the species of Polerovirus inducing yellow vein banding disease on chili pepper in Bali was PeVYV.

Table.1 Incidence of mosaic, yellow and chlorosis diseases on chili pepper in centre growing region of Bali

\begin{tabular}{lcccc}
\hline \multirow{2}{*}{$\begin{array}{l}\text { Sampling } \\
\text { Location }\end{array}$} & $\begin{array}{c}\text { Number of plant } \\
\text { observed (x1000) }\end{array}$ & Mercentage of chili pepper plants showing symptom of \\
\cline { 3 - 5 } & 5.12 & 32.4 & Yellowing & $\begin{array}{c}\text { Yellow vein } \\
\text { banding }\end{array}$ \\
\hline Badung & 4.86 & 30.8 & 23.5 & 0.0 \\
Bangli & 5.48 & 38.8 & 29.4 & 0.0 \\
Buleleng & 2.80 & 29.4 & 32.3 & 0.0 \\
Denpasar & 5.20 & 33.6 & 28.3 & 0.0 \\
Gianyar & 4.60 & 30.4 & 32.7 & 18.6 \\
Jembrana & 4.40 & 42.6 & 24.6 & 0.0 \\
Karangasem & 6.78 & 34.6 & 27.1 & 0.0 \\
Klungkung & 5.40 & 38.4 & 29.2 & 12.4 \\
Tabanan & Average & 34.6 & 29.2 & 15.8 \\
\hline \multicolumn{2}{r}{} & & &
\end{tabular}

Table.2 Percentage of chili pepper plants showing mosaic symptoms infected by Cucumber mosaic virus (CMV), Tobacco mosaic virus (TMV) or Chili veinal mosaic virus (ChiVMV) as verified by enzyme-linked immunosorbent assay (ELISA) using antisera to respective viruses.

\begin{tabular}{|c|c|c|c|c|}
\hline \multirow{2}{*}{$\begin{array}{l}\text { Sampling } \\
\text { Location }\end{array}$} & \multirow{2}{*}{$\begin{array}{c}\text { Number of plant } \\
\text { tested }\end{array}$} & \multicolumn{3}{|c|}{ Percentage of chili pepper plants infected by } \\
\hline & & CMV & TMV & ChiVMV \\
\hline Badung & 82 & 21.9 & 14.6 & 19.5 \\
\hline Bangli & 73 & 30.1 & 12.3 & 27.4 \\
\hline Buleleng & 104 & 30.7 & 17.3 & 21.2 \\
\hline Denpasar & 41 & 34.1 & 21.9 & 29.3 \\
\hline Gianyar & 86 & 25.5 & 11.6 & 28.5 \\
\hline Jembrana & 69 & 28.9 & 11.6 & 31.8 \\
\hline Karangasem & 92 & 34.8 & 15.2 & 30.4 \\
\hline Klungkung & 115 & 28.7 & 12.1 & 26.0 \\
\hline Tabanan & 103 & 30.0 & 15.5 & 23.3 \\
\hline & Average & 29.4 & 14.7 & 26.4 \\
\hline
\end{tabular}


Int.J.Curr.Res.Aca.Rev.2016; 4(10): 109-116

Table.3 Percent identity matrix of nucleotide sequences among Pepper vein yellows virus (PeVYV) isolates from Bali and around the world available in GenBank.

\begin{tabular}{lllcccccccccc}
\hline \multirow{2}{*}{ No } & PeVYV & GenBank & \multicolumn{10}{c}{ Percent Identity } \\
\cline { 3 - 13 } & isolate & Acc. No. & 1 & 2 & 3 & 4 & 5 & 6 & 7 & 8 & 9 & 10 \\
\hline 01 & Bali & - & ID & 99.1 & 99.0 & 98.6 & 98.6 & 98.5 & 98.1 & 98.0 & 98.0 & 62.4 \\
02 & Japan & AB594828 & & ID & 98.8 & 97.8 & 98.1 & 97.6 & 97.6 & 97.5 & 97.5 & 62.2 \\
03 & Taiwan & JX427542 & & & ID & 98.0 & 98.6 & 97.8 & 97.8 & 97.6 & 97.6 & 62.4 \\
04 & Thailand1 & JX427541 & & & & ID & 98.0 & 99.5 & 99.1 & 98.6 & 98.6 & 62.4 \\
05 & Filipina & JX427537 & & & & & ID & 97.8 & 97.5 & 97.3 & 97.3 & 62.4 \\
06 & Thailand2 & JX427539 & & & & & & ID & 99.3 & 98.5 & 98.5 & 62.6 \\
07 & India & JX427531 & & & & & & & ID & 98.1 & 98.1 & 62.4 \\
08 & Mali1 & JX427536 & & & & & & & & ID & 100 & 62.6 \\
09 & Mali2 & JX427535 & & & & & & & & & ID & 62.6 \\
10 & PLRV* & NC_001747 & & & & & & & & & ID \\
\hline
\end{tabular}

Fig.1 Three different viral symptom types, yellow vein banding (A), mosaic (B) and yellowing (C) affected chili pepper in Bali region.

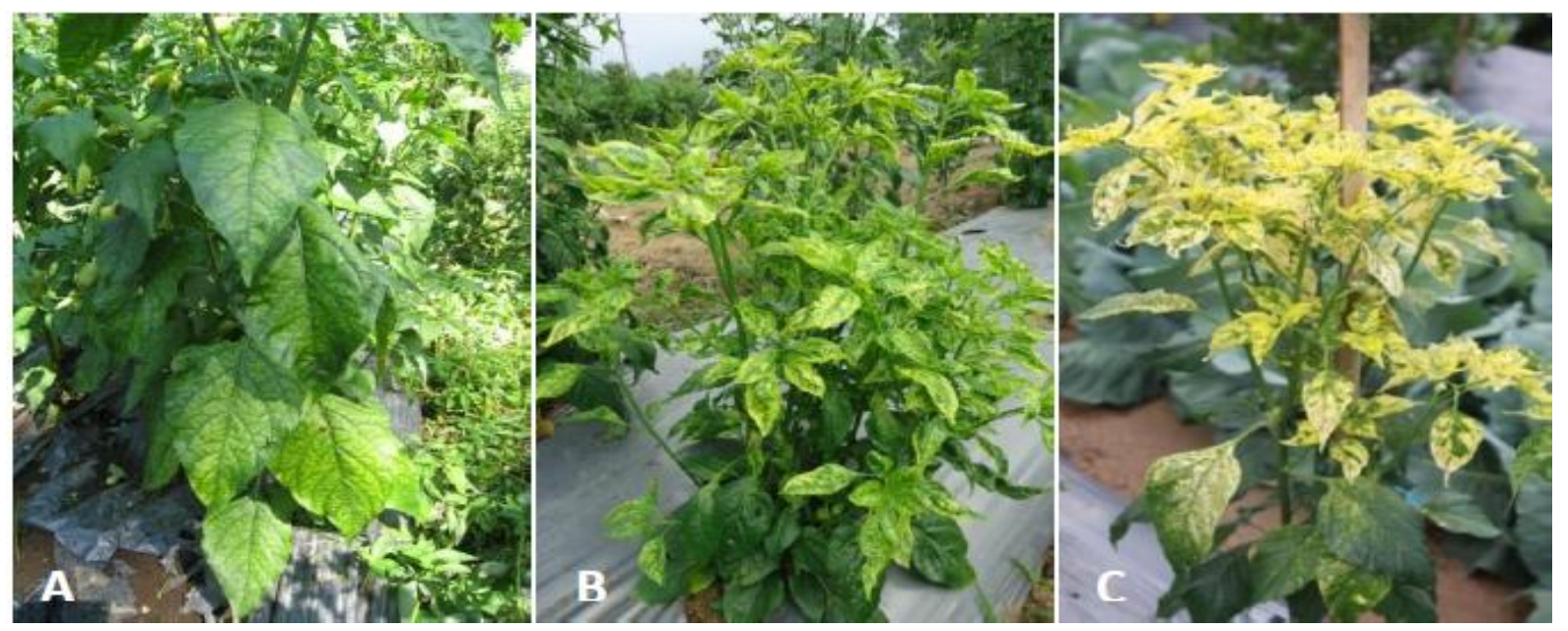

Fig.2 Reverse transcription-polymerase chain reaction (RT-PCR) using Polerovirus universal primer subjected to total RNA extracted from interveinal chlorosis exhibiting chili pepper plant sample 1, 2, and 3 obtained from Bali fields. $\mathrm{M}=100 \mathrm{bp}$ DNA ladder (Promega, USA) and $\mathrm{C}=$

Negative control (total RNA extracted from no any symptom exhibiting chili pepper plant).

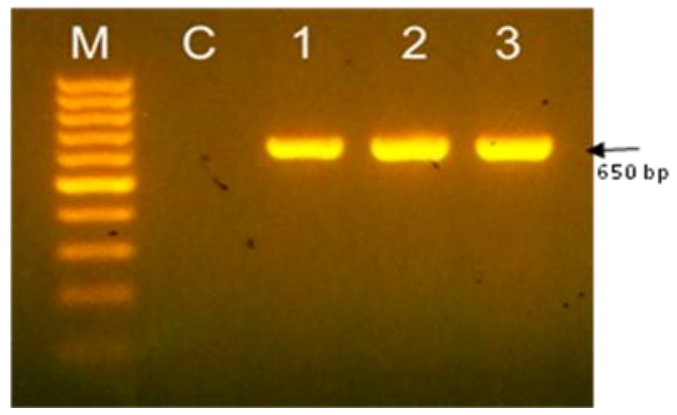


Fig.3 Phylogenetic analysis based on alignment of partial nucleotide sequences of Pepper vein yellows virus (PeVYV) isolates using Mega 6.06 (Algorithm Neighbour Joining with 1000 bootstraps replicates). Potato leaf roll virus (PLRV) was used as out group.

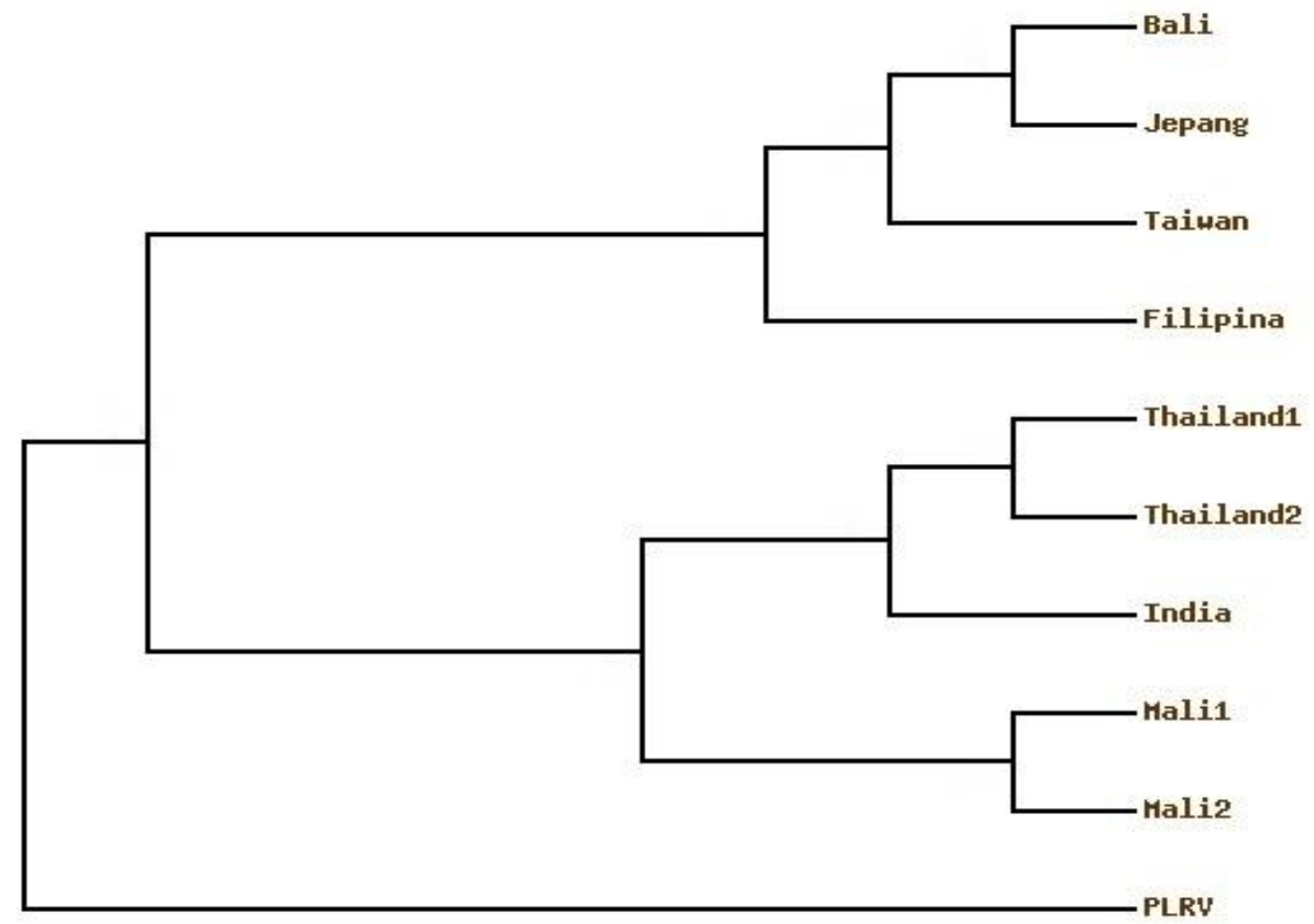

Further phylogenetic analyses to study their relationship showed that PeVYV infecting chili pepper from Bali belong to the same cluster with those of from Japan, Taiwan and the Philippine, and separated with the other cluster composed by PeVYV isolates from Thailand, India and Mali. This figure suggest that PeVYV in Bali may came from Japan, Taiwan or the Philippine through plant materials or insect vector.

\section{Conclusion}

The finding soft the present study demonstrated the occurrence of most of the common viruses causing severe damage in chili pepper in Bali region of Indonesia. Mosaic and yellowing were dominant disease, but yellow vein banding was newly emerging disease on chili pepper in Bali. CMV and ChiVMV played an important role in inducing mosaic disease. Yellow vein banding was a newly emerging disease present in chili pepper in Bali and it was confirmed that PeVYV infection was responsible for the disease.

\section{Acknowledgements}

The authors would like to thanks the Research Center and Community Services Udayana University, Directorate General of Higher Education, Ministry of Education and Culture of the Republic of Indonesia for providing research grant to support this study in the fiscal year 2014 to 2016.

\section{References}

Berke, T. 2002. The Asian Vegetable Research Development Center Pepper Project. Proceeding of the $16^{\text {th }}$ Int. 
Int.J.Curr.Res.Aca.Rev.2016; 4(10): 109-116

Pepper Conference,

Tampico.Tamaulipas, Mexico.

De Barro, P.J., S.H. Hidayat, D. Frohlich, S.

Subandiyah, U. Shiginori. 2008. A virus and its vector, Pepper yellow leaf curl virus and Bemisia tabaci, two new invaders of Indonesia. Biol. Invasions, 10(4): 411-433.

Green, S.K. 1991. Guidelines for diagnostic work in Plant virology. Asian Vegetable Research and Development Center. Technical Bull., No.15, Second Edition.

Nyana, D.N., G. Suastika, G.R.M. Temaja and D.N. Suprapta. 2012. Protective
Mild Isolates of Cucumber mosaic virus Obtained from Chili Pepper in Bali. J. Agri. Sci. Res., 2(6): 280-284.

Suastika, G., H. Sedyo, D.N. Nyana and T. Natsuaki. 2012. First Report on Polerovirus Infection on Chilipepper in Bali, Indonesia, J. Fitopatologi Indonesia, 8(5): 151-154.

Vos, J.G.M., A.S. Duriat. 1995. Hot pepper (Capsicum spp.) production on Java, Indonesia: toward integrated crop management. Crop Protection, 14: 205-213.

\section{How to cite this article:}

Nyana, I.D.N., T. Rahayuningsih, I.G.R.M. Temaja, G.N.A.S. Wirya and Suastika, G. 2016. New Status of Viral Disease Incidences on Chili Pepper in Bali, Indonesia: Emerging of Yellow Vein Banding Disease. Int.J.Curr.Res.Aca.Rev.4(10): 109-116.

doi: http://dx.doi.org/10.20546/ijcrar.2016.410.013 